\title{
Study on Labour Market Needs and Improvement in Employment Quality of College Students of Foreign Language Majors under the Belt and Road Initiative
}

\author{
Caigang Liu \\ School of Chemistry and Chemical Engineering \\ South China University of Technology \\ Guangzhou, 510641, China
}

\author{
Yifei Yang \\ School of Foreign Language \\ South China University of Technology \\ Guangzhou, 510641, China
}

\begin{abstract}
The construction of "the Belt and Road" inevitably needs more foreign language talents as the necessary guarantee. Through building the dimensions of needs for college students of foreign language majors such as the scale, structure and quality of employment market, it shows that the shortage of foreign language talents in countries and regions along "the Belt and Road" has become a practical problem restricting the implementation of " the Belt and Road " initiative. Therefore, this paper puts forward some new solutions to further improve the employment quality for college students of foreign language major. For example, it is necessary to come up with national language strategy, improve the training plan for foreign language talent and enhance individual comprehensive foreign language ability.
\end{abstract}

Keywords-The Belt and Road Initiative, college students of foreign language majors, labour market needs, employment quality

\section{INTRODUCTION}

In response to the profound changes and impacts of the global situation, China put forward the joint initiative of "the Silk Road Economic Belt" and "21s-century Maritime Silk Road" (hereinafter referred to as "the Belt and Road") in 2013, and "the Belt and Road" was called the "third reform and opening up" of China[1]. "The Belt and Road" runs through the continents of Asia, Europe and Africa, involving more than 60 countries and more than 100 cities. The diversity of language and culture has become the primary challenge for the promotion and implementation of the initiative. A large number of compound foreign language talents with international vision who are proficient in foreign languages, know foreign cultures and master certain professional knowledge are urgently needed. Therefore, the research on the labour market need and employment quality for college students of foreign language majors has become an important subject to promote the construction of "the Belt and Road".

II. THE IMPACT OF "THE BELT AND ROAD" ON THE LABOUR MARKET NEED FOR COLLEGE STUDENTS OF FOREIGN LANGUAGE MAJORS

Keynes' employment theory holds that the development of emerging industries and their related industries will inevitably generate new demand for labour force, thus bringing huge

Fund Project: Funded by South China University of Technology from the funds of basic research project of central institutions of high learning in 2019 employment space. [2] "The Belt and Road" initiative will undoubtedly bring great opportunities to the development of domestic industries and become an important force to promote the steady growth of the national economy.[3] The job demand for college students is associated with multiple factors such as national policy and economic environment. Under the influence of the "the Belt and Road" initiative, the job demand for college students of foreign language majors will be increasing. Certain changes will take place in the aspects of capacity, category and standard of job demand in order to adapt to the allocation of resources and economic development caused by "the Belt and Road" initiative.

\section{A. The increase of job market needs for college students of foreign languages}

With the rapid development of "the Belt and Road", there are more and more visions and opportunities for international cooperation with countries along "the Belt and Road". The Professional Report on Trade and Investment along the Countries and Regions of "the Belt and Road" firstly released by Chinese Academy of International Trade and Economic Cooperation in 2019 shows that in the "the Belt and Road" initiative, China has reached 17 free trade agreements with 25 countries and regions by the end of 2018. And an open and new economic pattern with the network in free trade area as the framework is emerging. At the same time, the scale and structure of China's trade with countries along "the Belt and Road" have been continuously improved, and the important trade in goods has been developing well. In 2018, the trade volume between China and countries along "the Belt and Road" reached 1.27 trillion US dollars.[4] The huge international investment has stimulated the demand for foreign language talents, thus the labour market needs for college students of foreign language majors who are familiar with other languages, cultures and industries has correspondingly expanded. The degree to which the labour market needs is satisfied has become a fundamental problem affecting the smooth development of "the Belt and Road". At the same time, Ministry of Education has also been increasing its support in key high-end language training and market supply. On the one hand, it supports colleges and universities to set up new majors in non-general foreign languages and realize the full coverage of the official languages of countries along "the Belt and Road". On the other hand, it works together with Ministry of Foreign 
Affairs, Ministry of Finance and other five ministries and commissions to issue the Notice on the Action Plan for Studying Abroad from 2015 to 2017, which explicitly proposed that China Scholarship Council will fund a large number of foreign language talents with relevant foreign language majors to go abroad for further study in order to accelerate the cultivation of foreign language talents for the construction of "the Belt and Road". The above measures exactly respond to the rapidly expanding labour market needs for college students of foreign language majors under the new pattern of "the Belt and Road".

\section{B. The increase of labour market needs for college students of foreign language majors in category}

The connectivity proposed in "the Belt and Road" is about people-to-people connectivity, which cannot be realized without the connectivity of language. In addition to the official languages certified by the United Nations, such as English, French, Russian, Spanish and Arabic, the official languages of countries and regions along the "the Belt and Road" include Persian, Turkish, Bengali and other minor languages. From the perspective of the development of foreign language education in China, almost all universities and colleges offer English major, and the cultivation of English talents plays an important role in foreign language education. However, labour market needs for college students of English major has tended to be saturated. Since 2006, English major has been in the ranks of majors with low employment rate in Max's employment report. In addition, there is a serious shortage of talents in minority languages in China. There are 53 official languages in countries along the "the Belt and Road". However, when the "the Belt and Road" initiative was put forward in 2003, only 20 languages were covered in the enrollment of foreign language majors in Chinese colleges and universities.[5] The job market for foreign language students has changed from a situation dominated by general language talents to one dominated by talents with minority languages under the new normal. With the increase of cooperation among countries along "the Belt and Road" and the coverage of minority languages of "Silk Road" is expanding, the labour market needs for foreign language students will increase correspondingly.

\section{The improvement of standards of labour market needs for college students of foreign language majors}

The industries involving in the construction of "the Belt and Road" include "transportation and aviation", "infrastructure industry chain", "energy construction", "commerce culture" and "information industry" [6]. Each industry involves different fields, thus the demand for foreign language talents varies from industry to industry, but all of them remain at a high level of demand. It is difficult for traditional pure language talents to adapt to the language communication in specific professional fields. Therefore, such compound talents with good command of foreign language and professional background are undoubtedly the best foreign language talents in the "Silk Road", which will inevitably raise the threshold of demand for college students of foreign language majors in the job market and thus raise the demand standard accordingly. Taking the demand standard for foreign language talents in foreign affairs industry in the building of "the Belt and Road" as an example, in addition to basic language skills, this industry also requires foreign language talents to have firm political belief, professional quality, good cross-cultural knowledge and certain professional background.[7] It can be seen that the compound talents with good command of foreign languages will become the normal demand standard for college students of foreign language majors in the job market in the construction of "the Belt and Road".

\section{The Construction of NeEd Dimension of Job Demand FOR COLLEGE STUDENTS OF Foreign LANGUAGE MAJORS UNDER THE INITIATIVE OF "THE BELT AND ROAD"}

\section{A. Analysis framework of labour market need for college students of foreign language majors}

The labour market demand for college students involves the whole and the partial demand, the quantity demand and the quality demand and so on, which is the concept for integrity and wholeness.[8] Its main demand contradiction concentrates on quantity, specialty and ability [9]. "The Belt and Road" initiative not only promotes new opportunities for economic and social development, but also brings great fluctuations to the job market demand for college students of foreign language majors. The three basic dimensions of the job demand for college students of foreign language majors can be constructed from the macro, the medium and the micro level, which are the scale demand, the structure demand and the quality demand respectively. The above three demand dimensions are surrounded with each other and progressive layer by layer, forming an onion-like structure, as shown in the figure. 


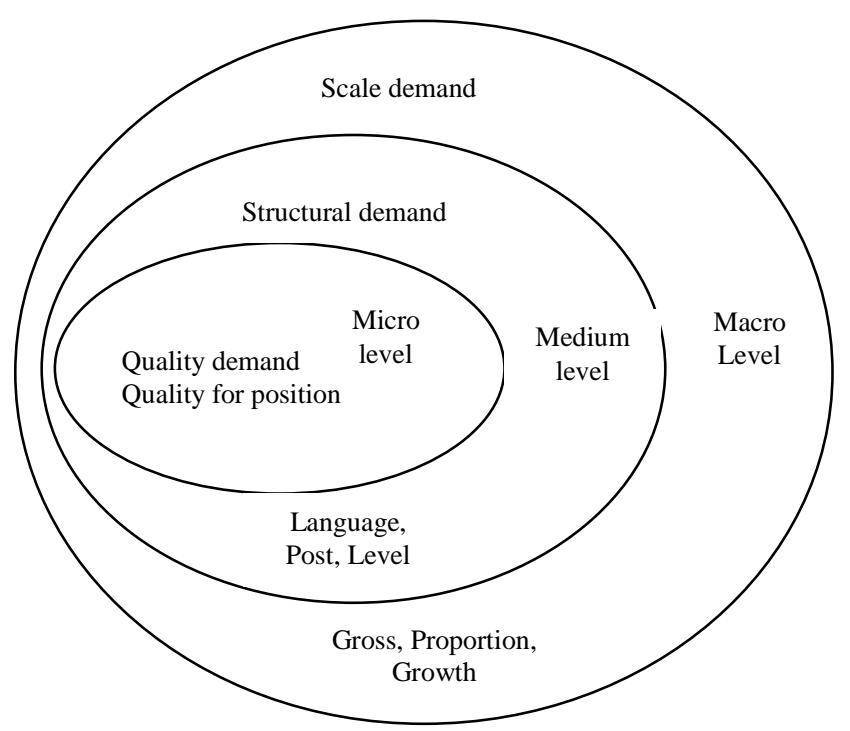

Fig. 1. Analysis framework of labour market demand for college students of foreign language majors

\section{B. Interpretation on the contents of the dimensions of job demand for college students of foreign language majors.}

1. In the aspect of macro level, that is the scale level. The demand for talents will be stimulated constantly under the background of open economy [10]."The Belt and Road" initiative aims to build a new system of China's open economy, which will continue to have a profound impact on the economic environment and economic layout. The scale of the job demand for foreign language students will also change. It is manifested in the three statistical indicators of total amount, proportion and growth demand, which complement each other and jointly illustrate the breadth of the scale of the labour market demand for foreign language students.

2. In the aspect of medium level, that is structural level. Industrial structure is closely related to job demand. "The Belt and Road" initiative emphasizes the formation of an all-round political, economic and cultural opening-up pattern, which will have a major driving force for the upgrading and adjustment of the domestic industrial structure and will put forward diversified requirements for the structural demand of college students of foreign language majors in the job market. On the one hand, the international development of various industries needs the support of foreign language talents, which is reflected in the change of job demand for different college students of foreign language majors. On the other hand, the external expansion of the industry will have a certain impact on the post setting of foreign language talents, which is reflected in the change of job structure in the job market. At the same time, the application and innovation of advanced technology in the process of internationalization in various industries have changed the level of demand, which is reflected in the change of the job demand for different level of college students of foreign language majors.

3. In the aspect of micro level, that is the quality level. "The Belt and Road" construction is a new round of development strategy of opening-up to the outside world based on the great achievements of China's reform and opening up, which involves in many industries and elements, many countries and regions and sets specific standard on the knowledge, ability and idea of foreign language talents which is reflected in the quality requirements in job market including character, knowledge, ability, values and other factors.[11] With the expansion and implementation of "the Belt and Road" initiative, the market demand for foreign language talents continues to expand, and the quality requirements are also improved, which means that college students of foreign language majors will face more serious post competence challenges in the job market.

\section{ANALYSIS OF THE PATH FOR THE IMPROVEMENT OF EMPLOYMENT QUALITY FOR COLLEGE STUDENTS OF FOREIGN LANGUAGE MAJORS UNDER "THE BELT AND ROAD" INITIATIVE}

\section{A. At the national level: speeding up the design for cultivation of the high quality foreign language talents}

Under the vision of "the Belt and Road", China's economic development is also faced with the problem of language communication. The employment market of college students of foreign language majors shows an expanding trend in terms of scale demand, especially increasing the demand for talents in minority languages, international positions and foreign language talents with high-level education background. However, there is a shortage of relevant language talents in the supply end. At present, the demand expectation does not match with the actual employment. In response to the actual connectivity between the demand for foreign language talents and their cultivation caused by the implementation of "the Belt and Road" initiative, our country should take it into a thorough consideration in the long term from the perspective of macroscopic level, speed up the design for the cultivation of high quality foreign language talents, which is also a sound coordination and balance among market demand, students development and the law of disciplines.[12] Specifically, we may refer to the practice of western developed countries. They launch national language strategy, bringing the foreign 
language talents cultivation and reserves into national strategic level, researching and evaluating their cultivation nationwide and the situation of market demand in a top-to-bottom manner, and mastering all kinds of information on the distribution, recruitment, training and employment of foreign language talents. Thus, according to the real demand, it should implement the corresponding special construction for foreign language learners and make a further clear of and coordinate key issues such as market positioning, major distribution, recruitment policy and training mechanism in the hope of making breakthrough in the demand for language talents under the initiative of "the Belt and Road" from the national macroscopic level, thus providing policy support for the employment quality of college students of foreign language majors.

\section{B. At the institutions of high learning level: improving the plan of cultivation for foreign language talents in a reasonable way.}

It is required to match the cultivation of talents in institutions of high learning with job demand in quantity, structure and quality, which is the important premise to promote educational reform in higher learning and boost economic and social development. [13] In the process of implementation of "the Belt and Road" initiative, the weaknesses are exposed in job market for college students of foreign language majors. For example, the cultivation mode is inconsistent with the actual need of employers, which leads to the structural shortcoming in relevant language talents. In order to meet the urgent need of national strategic development for relevant language talents, institutions of high learning should actively seize the opportunity to cultivate foreign language talents and reasonably improve its training plan. On the one hand, colleges should make efforts to meet the relevant entry threshold and qualification standards in the application for the opening of new language majors based on the objective conditions and practical needs, so as to lay a solid foundation for the talent cultivation of non-general minority languages; On the other hand, according to the original language majors, colleges should consciously combine with market demand to redefine the orientation of cultivation for foreign language talents and consider the applicability of inter-disciplinary talent training mode such as the mode of "general language and other majors" "general language plus non-general language" "multilingual and other majors", thus constantly promoting their employment quality.

\section{At individual level: making effort to strengthen personal employment ability.}

There is a positive correlation between college students' employability and employment quality, and individual employability will continue to affect their employment quality.[14] High-level foreign language talents with solid language skills, familiar with the background culture of the target country, professional knowledge of international trade and law, and strong comprehensive quality are the key talents who can really pave the way for the language communication of "the Belt and Road" initiative. The first is to establish compound and international development direction. College students of foreign language majors should pay close attention to the general trend of national development, understand the dynamic demand of "the Belt and Road" initiative for language talents and its impact on the employment prospects for foreign language majors and set up the compound international development direction. The second is to develop professional interests outside the language. The construction of "the Belt and Road" involves international trade and investment, crossborder e-commerce, foreign contracting projects and other international cooperation. Thus there is a huge demand for translators with relevant professional knowledge in trade, finance, law and other fields. Therefore, in addition to mastering the professional skills of languages, they should also accumulate other professional knowledge through double degrees, double majors or minor courses. The third is to improve comprehensive quality and capacity in an all-round way. Investment layout, custom differences among countries and cross-cultural communication under the "the Belt and Road" initiative will pose more severe challenge to the real cooperation, which requires college students of foreign language majors to improve their abilities in expression, communication and coordination and problem-solving in an all-round manner, and constantly enhance their employment ability, thus further improving the employment quality.

\section{CONCLUSION}

Foreign language talents are the necessary conditions for the smooth implementation of "the Belt and Road" initiative. With the continuous improvement of cooperative scale and quality of "the Belt and Road", the employment market of foreign language talents has undergone corresponding changes in the scale demand, structure demand, quality demand and other aspects. And there are certain contradictions between the demand expectation and the actual employment. In order to further improve the employment quality and level of college students of foreign language majors, it is necessary to make joint efforts from the level of nation, institutions of high learning and individuals to strengthen top-level design and launch the national language strategy, make up for the shortcomings of education, improve the training plan for foreign language talents, clarify the direction of development and enhance the individual comprehensive foreign language ability. Meanwhile, the continuous improvement of employment quality of foreign language talents will further boost the construction of "the Belt and Road" to achieve greater results.

\section{REFERENCES}

[1] Wei Jianguo, The Belt and Road: China's Third Reform and Opening up Strategy [J]. Foreign Investment in China, 2015(1):24-25

[2] Niu Linhao, Analysis on the Difficulty of Employment for Current College Students Based on Keynes Theory of Employment [J]. China University Students Career Guide, 2014(18):6-9

[3] Wang Wensen, Peng Xijun, Wang Xueliang, On Seizing the Strategic Opportunity of "the Belt and Road" to Promote the Economic Development of Guangdong[J]. Guangdong Economy, 2015(11):48-56

[4] China Business Network. Fruitful Results of Trade and Investment of "the Belt and Road" Released By the Report of the Development of 
Trade and Investment of "the Belt and Road", [EB/OL].https://www.yicai.com/news/100175517.html.2019-04-27.

[5] Luo Xu, Don't Let the Shortage of Talents of Minority Language Affect the Development of "the Belt and Road [N]. Guangming Daily, 2017.08.05(15)

[6] China Network, The Construction of National Language Ability Meets People's Needs in Countries Along "the Belt and Road"[EB/OL].

http://news.

china.com.cn/world/201609/26/content_39373397.htm.2016-09-26.

[7] Wang Jin, Wu Guolian, Chen Na, Shi Tinglan, Research on the Requirements for Foreign Language Talents and its Corresponding Measures Under the Initiative of "the Belt and Road". [J] Modern Marketing, 2016(5):78-79

[8] Hao Xue, Research on the Setup of Majors in Market-Oriented Applied Technology Colleges [D]. Harbin University of Science and Technology, 2015
[9] Luo Xiu, On the Job Expansion of College Students from the Perspective of the Supply and Demand of Job Market[J]. China Adult Education, 2008(22):29-30

[10] Zhu Zhiming, What Are New Requirements for Talents Brought by Open Economic System[J]. China Talents, 2014(6):26-28

[11] Zhao Shuming, On the Ability of Employees with High Quality, Enthusiasm and Coordination and Reconstruction of the System of Human Resource in Enterprises[J]. Reform, 2011(6):137-140

[12] Wen Qiufang, On Cultivation of Language Talents under "the Belt and Road" Initiative [J]. Chinese Journal of Language Policy and Planning, 2016(2):26-32.

[13] Cao Xiaoli, Lin Mei, Research on the Cultivation of Talents in Institutions of High Learning and Job Demand from the Perspective of Employability- A Case Study of Tianjin[J] Bohai Rim Economic Outlook, ,2013(10):32-35.

[14] Chen Wei, Xun Jinmin, Research on the Relationship between Employment Ability of College Students and Employment Quality [J]. Education and Vocation, 2016(18):80-84 